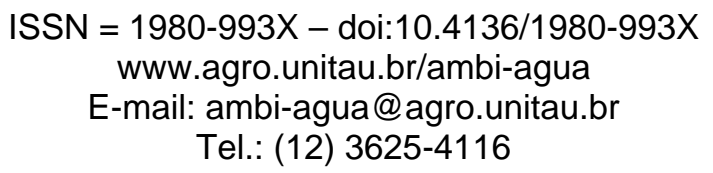

\title{
Metodologia para elaboração de mapas hidrogeológicos: estudo de caso da bacia hidrográfica do rio da Palma, DF, Brasil (doi:10.4136/ambi-agua.26)
}

\author{
1 \\ Tatiana Diniz Gonçalves ; José Eloi Guimarães Campos ; Getulio Teixeira \\ Batista $^{2}$; Hélio Nóbile Diniz ${ }^{2}$; Marcelo dos Santos Targa \\ 1Universidade de Brasília. Instituto de Geociências, Campus Universitário Darcy Ribeiro, Asa Norte \\ E-mail: tatidg@terra.com.br; eloi@unb.br \\ ${ }^{2}$ Programa de Pós-Graduação em Ciências Ambientais, Universidade de Taubaté \\ E-mail: \{getulio;mtarga\}@agro.unitau.br; heliodiniz1@yahoo.com.br
}

\section{RESUMO}

Este trabalho teve por objetivo apresentar uma metodologia para subsidiar a gestão de recursos hídricos por meio da cartografia hidrogeológica, testada para a situação hidrogeológica da bacia do rio da Palma, localizada na região Central do Brasil. Como resultado, obtiveram-se dois produtos: o mapa hidrogeológico e o mapa de potencial de infiltração e recarga do alto curso da bacia do rio da Palma. Este trabalho está dividido em seis partes. A primeira corresponde à discussão sobre os elementos do mapa, os mapas temáticos essenciais e as escalas apropriadas. Na segunda, é apresentada uma proposta de critérios gráficos para representação integrada dos principais parâmetros de aqüíferos sobrepostos. Na terceira parte, é mostrada a importância da base de dados para a cartografia hidrogeológica, isto é, a contribuição de cada tema, com destaque para solo, geologia, declividade, clima e uso e cobertura vegetal, quando adequadamente integrados. A quarta parte aborda a escolha e a integração dos principais planos de informação da bacia do rio da Palma em um SIG (Sistema de Informação Geográfica). Na quinta parte, é mostrado o resultado da integração dos sistemas aqüíferos do domínio poroso com os do domínio fraturado e, finalmente, é apresentado o mapa de potencial de infiltração e recarga da área estudada, elaborado a partir da integração dos planos de informação da base de dados. De forma geral, na área estudada, predominaram as regiões com potencial de infiltração alto e moderado, em que a interferência humana ainda é incipiente. Grande parte das regiões de potencial baixo está relacionada às altas declividades, onde prevalecem os cambissolos ou à presença de edificações urbanas.

Palavras-chave: Hidrogeologia; SIG; recarga de aqüíferos.

\section{Methodology for generation of hydrogeologic maps: rio da Palma watershed case study, DF, Brazil}

\begin{abstract}
This paper had the objective of developing a methodology to support the management of water resources based on hydro geological cartography, validated for the hydro geologic conditions of a watershed located at Central Brazil. Results show two major products: a hydro geologic, and a potential infiltration and recharge maps of the high course of the Rio da Palma watershed. This paper is presented in six parts. The first one discusses the map's elements, essential thematic maps and appropriate scales. The second part proposes the graphic criteria
\end{abstract}


for the integrated representation of the major parameters of overlaying aquifers. The third part demonstrates the importance of the data basis for the hydro geologic cartography, i.e., the contribution of each theme such as soil, geology, slope, climate and land use, when appropriately integrated. The fourth part discusses the selection and the integration of the main information layers for the Rio da Palma watershed using a Geographic Information System (GIS). On the fifth part, the result of the integration of the porous domain with the fractured domain aquifer information layers is shown and, finally, the potential infiltration and recharge map of the studied area, elaborated from the integration of overlapping of the data basis information layers is presented and discussed. In general, in the studied area, regions with high infiltration potential prevail where human interference is still moderate. Large portions of low infiltration potential are either associated with high slopes, with shallow soils (Cambissolos) or else with urban constructions.

Keywords: Hydrogeology; GIS; aquifer recharge.

\section{INTRODUÇÃO}

A água subterrânea é uma importante alternativa de abastecimento. A implementação de Planos Estaduais de Recursos Hídricos impulsionou novos progressos na área da hidrogeologia, tanto em termos de métodos exploratórios como de gerenciamento das águas subterrâneas.

A representação gráfica da informação hidrogeológica vem sendo utilizada, cada vez mais freqüentemente, como ferramenta indispensável para o planejamento do uso das águas subterrâneas. Essa representação deve refletir a situação atual do conhecimento hidrogeológico e atender às necessidades específicas dos gestores desses recursos. Estudos hidrogeológicos básicos e observações em campo, principalmente quando da perfuração de poços tubulares profundos nos diversos ambientes discriminados na região, fornecem informações sobre os tipos pedológicos, geologia, níveis freáticos, direções de fluxo, comportamento de zonas saturadas e não saturadas, vocação hidrogeológica das rochas, os quais, reunidos, subsidiaram a elaboração dos modelos (Lousada; Campos, 2005) e mapas.

Os mapas hidrogeológicos são considerados, segundo Mente (2000), produtos gráficos resultantes do conhecimento no domínio das ciências da água, e, são elaborados, principalmente, para sintetizar as informações disponíveis sobre as condições hidrogeológicas e as águas subterrâneas, com a finalidade de fornecer uma visão do arcabouço hidrogeológico regional de determinada região. Apesar do amplo conhecimento local, a confecção do mapa hidrogeológico da porção distrital do rio da Palma, em escala detalhada, ainda não havia sido realizada. Desse modo, neste trabalho, a metodologia cartográfica é empregada numa área específica no Distrito Federal, o alto curso da bacia do rio da Palma, de forma a subsidiar o conhecimento das condições de infiltração e recarga dos aqüíferos da região.

\section{MATERIAIS E MÉTODOS}

Para desenvolver este trabalho foram aplicados, basicamente, dois métodos:

O primeiro diz respeito à proposição de uma metodologia para a cartografia hidrogeológica, principalmente para casos em que ocorram aqüíferos superpostos. Esse procedimento deve ser baseado em mapas e elementos cartográficos existentes, além da geração de novas informações; 
O segundo foi a aplicação desta proposta em uma bacia específica situada no Distrito Federal, de forma a se determinar a efetividade do procedimento proposto.

A integração da base de dados utilizada para a geração do Sistema de Informação Geográfica (SIG) e desenvolvimento do trabalho foi realizada com auxílio do aplicativo ArcView, e a análise e classificação das imagens foi realizada por meio do aplicativo Envi.

\section{RESULTADOS E DISCUSSÃO}

\subsection{Mapas Temáticos}

Na cartografia temática não se podem expressar todos os fenômenos em um mesmo mapa e a solução é, portanto, diversificá-los. Assim, os mapas temáticos devem fornecer com o auxílio de símbolos qualitativos e/ou quantitativos dispostos sobre uma base de dados, geralmente extraída dos mapas e cartas topográficas, informações referentes a determinado tema ou fenômeno presente no território mapeado (IBGE, 2005).

Sob a visão conceitual do cartógrafo Barbosa (1977), os mapas temáticos são classificados em três tipos: mapas de notação, estatísticos ou de síntese. Os mapas de notação registram os fenômenos na sua distribuição espacial, sob a forma de cores ou de tonalidades muito variadas, complementadas muitas vezes por sinais gráficos característicos. A ênfase da variação aparece no destaque das diferenças qualitativas do fenômeno ocorrido na área para o fenômeno variante que se observa em outra área, e assim por diante. Como exemplo, pode-se citar: o mapa geológico, o pedológico, o de uso da terra, etc.

Os mapas estatísticos são os que contêm os elementos primários do tema, elaborados cartograficamente, e são originários de técnicas estatísticas, tanto no que se refere aos elementos físicos, quanto aos elementos humanos. Assim, caracterizam-se os mapas de densidade, os de distribuição de pontos, os de fluxo, os pluviométricos e os mapas de isolinhas.

Os mapas de síntese têm finalidade explicativa, em que a representação de um fenômeno, em conjunto, é realizada mediante as suas relações externas. Os mapas de síntese expressam o conjunto dos elementos de diferentes fatos ou fenômenos, formam uma abstração intelectual, apresentando-se de forma global. Podem ser considerados de síntese os mapas hidrogeológicos, os morfoestruturais, os geomorfológicos, os históricos, etc.

\subsection{Cartografia Hidrogeológica}

O mapa hidrogeológico busca representar a potencialidade ou produtividade dos aqüíferos, a importância hidrogeológica relativa local e as características gerais dos sistemas aqüíferos. Fornece, também, a partir de uma base geológica simplificada, as características litológicas gerais de cada unidade, o que, em linhas gerais, acaba por determinar a vocação hidrogeológica dos aqüíferos delimitados (Mente, 2000).

Os critérios utilizados para classificar diversos gêneros de mapas hidrogeológicos variam de acordo com o tema, conteúdo, apresentação, escala, método de produção, etc. Desses critérios, aqueles tomados como os mais decisivos são: o propósito do mapa, seu possível uso, o estado dos dados disponíveis ou o nível de informação.

Basicamente, distinguem-se dois tipos de mapas hidrogeológicos: os sistemáticos / generalizados, que são representações gráficas de um inventário sistemático e centralizado de dados geológicos e hidrogeológicos e, os mapas derivados, que se destinam a servir a projetos específicos e a demandas especiais.

A visão sistemática e homogênea das condições hidrogeológicas assume grande valor à medida que permite identificar estruturas hidrogeológicas coerentes com os sistemas de 
fluxos subterrâneos, propicia o conhecimento das relações hidrogeológicas com suas áreas limites, revela lacunas nas informações hidrogeológicas, amplia o escopo e estabelece a base de futuras informações sistemáticas para complementar inventários. Já os mapas hidrogeológicos derivados são orientados, normalmente, para solucionar problemas e servir a usuários bem específicos, o que os difere daqueles por sua contribuição substancial não só ao entendimento do mapa em si, mas também, ao conhecimento específico para o planejamento, o desenvolvimento e a proteção dos recursos hídricos subterrâneos.

\subsection{Escala}

A escala representa a razão entre o comprimento em mapa e o verdadeiro comprimento existente na superfície da terra. A escala pode variar em função dos parâmetros a serem analisados e do nível de detalhamento que se pretende dos mapas hidrogeológicos e, é função direta das informações disponíveis da área de pesquisa e dos conhecimentos regionais sobre a geologia, os solos, a topografia e sobre as águas subterrâneas. Para exemplificar, a Tabela 1 apresenta as características dos mapas de solos.

Tabela 1. Características dos mapas de solos em função da finalidade dos levantamentos.

\begin{tabular}{|c|c|c|c|}
\hline $\begin{array}{c}\text { Tipo de } \\
\text { Levantamento }\end{array}$ & $\begin{array}{l}\text { Escala de } \\
\text { Publicação }\end{array}$ & $\begin{array}{c}\text { Área mínima } \\
\text { mapeável }\end{array}$ & Finalidade \\
\hline Ultradetalhado & $>1: 10.000$ & $<0,4$ ha & $\begin{array}{l}\text { Planejamento e exploração de } \\
\text { áreas muito pequenas }\end{array}$ \\
\hline Detalhado & $\begin{array}{l}1: 10.000 \mathrm{a} \\
1: 25.000\end{array}$ & 0,4 a 2,5 ha & Projetos conservacionistas \\
\hline Semidetalhado & $\begin{array}{l}1: 25.000 \mathrm{a} \\
1: 100.000\end{array}$ & 2,5 a 40 ha & $\begin{array}{l}\text { Planejamentos de uso e } \\
\text { conservação dos solos }\end{array}$ \\
\hline Reconhecimento & $\begin{array}{l}1: 100.000 \mathrm{a} \\
1: 750.000\end{array}$ & 0,4 a $22,5 \mathrm{~km}^{2}$ & $\begin{array}{l}\text { Mapa básico }- \text { visa } \\
\text { planejamento de novas áreas }\end{array}$ \\
\hline Exploratório & $\begin{array}{l}1: 750.000 \mathrm{a} \\
1: 2.500 .000\end{array}$ & 22,5 a $250 \mathrm{~km}^{2}$ & $\begin{array}{l}\text { Conhecimento de grandes áreas } \\
\text { não desbravadas }\end{array}$ \\
\hline
\end{tabular}

A escala dos mapas geológicos segue, basicamente, os mesmos critérios dos mapas de solo, entretanto, deve-se atentar ao fato de que, em escalas maiores, os mapas geológicos, em muitas situações, não permitirão discriminar mais que uma ou duas unidades. Por outro lado, parâmetros como, densidade de fraturas, que são ignorados em escalas menores, devem ser levados em consideração em escalas maiores, superiores a 1:25.000, por exemplo.

De acordo com o IBGE (2005), para que se tenha boa representação em mapas, a extensão dos acidentes topográficos da região em estudo deve ser considerada. Assim, a menor escala para mapear certa região da superfície terrestre que tenha acidentes em torno de 10 m de extensão será: $M=10 \mathrm{~m} / 0,0002 \mathrm{~m}=100.000 / 2=50.000$. Nesse caso, a escala adotada deverá ser igual ou maior que 1:50.000. Nessa escala, o erro prático $(0,2 \mathrm{~mm})$ corresponde a $10 \mathrm{~m}$ no terreno.

Contudo, não é comum trabalhos com mapas hidrogeológicos em escalas maiores que 1:50.000. Nessa escala, os mapeamentos são considerados semidetalhados e a intensidade de observações poderá variar segundo o método utilizado.

De acordo com Vink (apud Vieira, 1988), a fotointerpretação é um método que utiliza prévia interpretação de imagens de satélite e/ou fotografias aéreas para identificar e discriminar feições de interesse para posterior verificação no campo. A experiência tem demonstrado que os mapas resultantes são bastante precisos e revelam claramente a relação geográfica entre as feições e as condições que eles apresentam. 


\subsection{Cartografia de Aqüíferos Superpostos}

No Brasil, vários estudos de cunho hidrogeológico foram desenvolvidos visando melhorar a representação das informações hidrogeológicas em mapas e segundo Campos (2004) as principais informações sobre a hidrogeologia do Distrito Federal estão disponíveis nos trabalhos de Romano e Rosas (1970), Barros (1987, 1994), Amore (1994), Mendonça (1993), Campos e Silva (1998), Zoby (1999), Souza (2001), Joko (2002), Cadamuro (2002). Entretanto, apenas Campos e Silva (1998) propõem, para o Distrito Federal, a cartografia para aqüíferos superpostos. Esta cartografia visa representar os principais parâmetros tanto dos aqüíferos fraturados quanto dos aqüíferos do domínio poroso que os recobrem.

Os parâmetros essenciais e suas representações gráficas para a cartografia de aqüíferos sobrepostos podem ser abordados da seguinte maneira:

a) Base Hidrográfica: - curso d’água perene (linha azul contínua), curso d’água intermitente (linha azul tracejada), lagoa permanente (contorno cheio azul liso), lagoa intermitente (contorno cheio azul tracejado), barragens (contorno cortado cheio azul liso), áreas sujeitas à inundação (tracejado grosso azul sem contorno), fontes (ponto azul), reservatórios (ponto preto).

b) Geologia: - Unidades Geológicas - letras e números, exemplos: PPC - Unidade Psamo Pelito Carbonatada, $\mathbf{R}_{\mathbf{4}}$ - Unidade Metarritmito Argiloso.

c) Estrutural - simbologia de linhas e setas variadas conforme Figura 1.

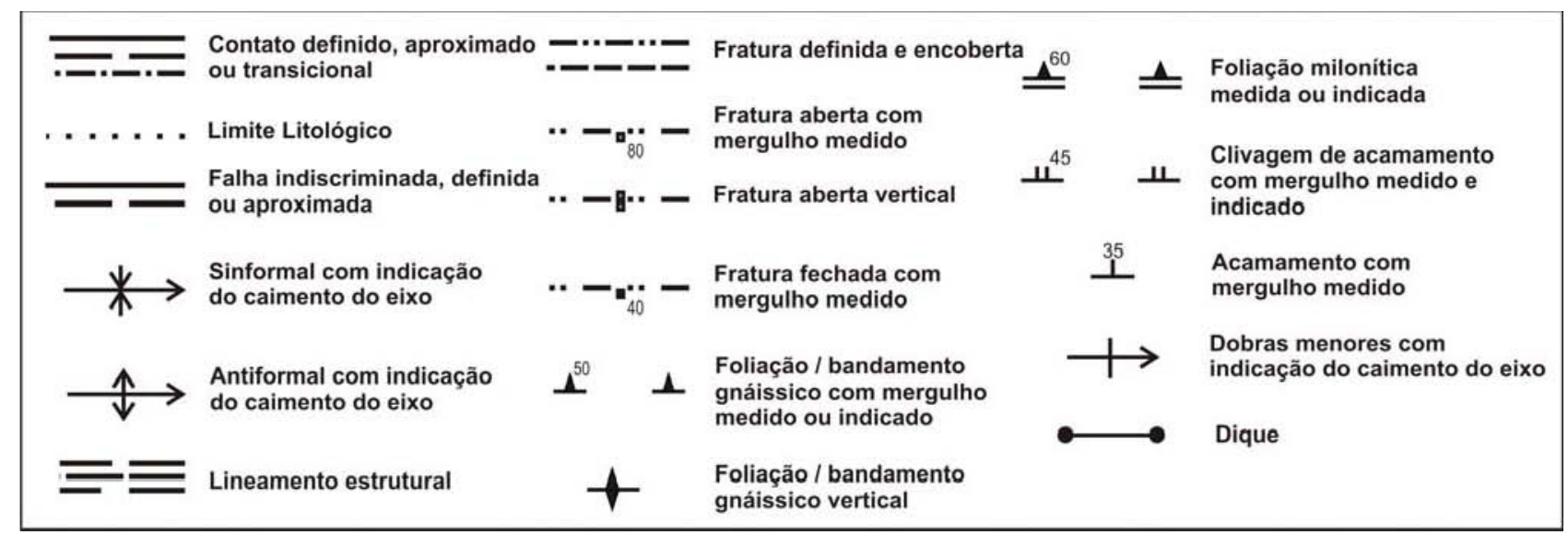

Figura 1. Simbologia para definir estruturas geológicas.

d) Área de exposição dos aqüíferos: Intergranulares - hachuras, Fraturados - cores; principais áreas de recarga - pontilhado grosso;

e) Uso da água - letra maiúscula como segue: Consumo humano - H, Consumo animal - G, Irrigação - I, Abastecimento industrial - F.

Os parâmetros acessórios podem ser abordados da seguinte maneira:

a) Condições das áreas de exposição dos aqüíferos diferenciadas por cores, exemplos: - Área de recarga com alta condutividade hidráulica, Área de descarga do aqüífero livre, Área sobrexplotada, Área de descarga de aqüíferos cársticos, etc.

b) Produtividades dos aqüíferos: - devem ser indicadas por valores médios da capacidade específica para cada unidade hidroestratigráfica, por exemplo: - Muito alta (maior que 1,11 l/s/m), Alta (entre 0,44 - 1,11 l/s/m), Média (entre 0,11 - 0,44 l/s/m), Baixa (entre 0,033 - 0,11 l/s/m), Muito baixa (menor que 0,033 l/s/m). 
Outros mapas que devem ser considerados são: Mapa das Unidades Geomorfológicas, Mapa de Declividade, Mapa de Densidade de Drenagem, Seção Geológica Esquemática e Diagrama de Pluviometria.

\subsection{Os Tipos de Mapas}

Os mapas topográficos são considerados básicos, tendo em vista que vários outros mapas são derivados deles. Um dos seus subprodutos muito utilizado nos estudos hidrogeológicos é o mapa de declividade.

Atualmente, a utilização de softwares como o ArcView, SPRING, IDRISI e outros, tem proporcionado a confecção de mapas de declividade muito sofisticados. Em um ambiente computacional, as curvas de nível, os pontos cotados e a hidrografia constituem planos de informação que, integrados num dos softwares mencionados, são processados, resultando num Modelo Digital de Elevação (MDE). O MDE pode ser definido como um modelo matemático que reproduz uma superfície real a partir de algoritmos e de um conjunto de pontos (x,y), em um referencial qualquer, com atributos denotados de $\mathrm{z}$, que descrevem a variação contínua da superfície (Burrough, 1986). O MDE é comumente utilizado para denotar a representação quantitativa de determinada grandeza que varia continuamente no espaço.

O mapa de declividade derivado do MDE é indispensável para estudos hidrogeológicos, uma vez que a inclinação do terreno é determinante da sua taxa de infiltração. Quanto maior a declividade, menor a infiltração de água e vice-versa.

Outro subproduto do mapa topográfico é a hidrografia, que pode ser representada de acordo com o tipo de drenagem. Normalmente na cor azul, as linhas de drenagem descrevem os cursos d'água intermitentes (tracejado) e perenes (liso).

O conhecimento da geologia de uma região é o ponto de partida para a compreensão da distribuição espacial dos aqüíferos, entendidos aqui como formações geológicas capazes de armazenar e transmitir água. Os mapas geológicos, além de identificarem a litoestratigrafia e estruturas geológicas de determinada área, fornecem informações sobre as características dos aqüíferos, sua distribuição, extensão lateral, áreas de recarga e exutório, camadas confinantes e bases impermeáveis.

As unidades geológicas são, geralmente, discriminadas nos mapas por cores, de acordo com a litologia e/ou por letras abreviadas maiúsculas e minúsculas.

Em estudos hidrogeológicos comumente se classificam as unidades geológicas de acordo com a importância das rochas para os aqüíferos, em função das suas propriedades intrínsecas (porosidade e permeabilidade), condições de ocorrência (extensão, espessura e estrutura) e explotabilidade (fácil, regular ou difícil).

Os mapas de lineamentos são utilizados para constatação do padrão e da densidade de fraturamentos e falhamentos de determinada região. A contribuição deste estudo é significativa para a hidrogeologia na medida em que a densidade dessas estruturas evidencia as direções preferenciais de fluxo da água subterrânea em aqüíferos fraturados.

Esses mapas podem ser confeccionados a partir de fotografias aéreas e/ou imagens de satélite de alta resolução e, ainda, por meio de medidas realizadas em campo com bússola.

A representação em mapas desses elementos estruturais é, geralmente, por meio de traços e setas, diagramas de fraturas e, ainda, de pequenos mapas de densidade de fraturas.

Os mapas hidroquímicos têm por finalidade, em estudos hidrogeológicos, identificar e quantificar as principais propriedades e os constituintes químicos das águas subterrâneas, procurando estabelecer uma relação com o meio físico. 
Podem ser representados por mapas de isoteores (isolinhas que correspondem a linhas de mesmo teor de determinada substância), por gráficos, símbolos ou figuras que representem a composição química das águas e, ainda, por diagramas, sendo os mais utilizados os de Piper (Bovolato, 2006), Collins Stiff e os circulares (Melo Júnior et al., 2003).

Os mapas de solos disponibilizam a localização das classes de solo em função da escala de mapeamento. Esta informação é relevante nos estudos hidrogeológicos porque, ocasionalmente, os limites entre manchas de solos coincidem com contatos geológicos e cada classe de solo tem uma organização nas direções lateral e vertical, fundamentais à caracterização de aqüíferos porosos.

A caracterização de aqüíferos do sistema poroso é normalmente determinada de acordo com os valores de condutividade hidráulica e transmissividade. A variação dos valores de condutividade hidráulica e transmissividade é função do tipo de solo e, principalmente, do teor de argila desses solos. Quanto mais argilosos, menores serão os valores esperados. As feições texturais dos solos também apresentam importância específica, visto que solos argilosos ou muito argilosos podem apresentar valores de condutividade hidráulica significativamente maiores no caso de apresentar forte estrutura granular. As classes de solos em mapa são representadas por cores.

Os mapas geomorfológicos representam o padrão de relevo que predomina em cada compartimento morfológico. O conhecimento das formas de relevo é de suma importância para a definição dos tipos de fluxo hidrogeológico das diversas bacias hidrográficas, bem como na definição das principais áreas de recarga. A compartimentação geomorfológica de determinada região é comumente representada em mapas por hachuras de diferentes inclinações.

Os mapas de uso e cobertura vegetal são necessários aos estudos hidrogeológicos para avaliação regional das áreas potenciais de maior ou menor recarga. Dependendo do tipo de uso ou de cobertura da terra, haverá variação na resposta à infiltração de água.

Os mapas de uso e cobertura vegetal podem ser construídos a partir da interpretação de imagens de satélite ou fotografias aéreas. Com o auxílio de sofwares especializados como o ENVI ou o SPRING, por exemplo, tem-se a opção de classificar o tipo de uso e cobertura nas imagens. Os resultados desses métodos são comprovadamente satisfatórios e o produto final é um mapa digital temático cujas classes representativas de cada feição são discriminadas por cores. Existem estudos que buscam padronizar as cores de cada classe para trabalhos científicos.

Os mapas de isoietas são representados por isolinhas que correspondem a um mesmo valor de altura pluviométrica. Esses mapas são fontes de informações das tendências pluviométricas de determinada região. Esses mapas são utilizados para estimativa da distribuição espacial da altura pluviométrica, visando ao cálculo do balanço hídrico. A representação nos mapas é feita por faixas de cores ou por variações tonais (Carvalho; Assad, 2002).

\subsection{Aplicação - Estudo de Caso}

\subsubsection{A bacia do rio da Palma}

O alto curso da bacia do rio da Palma, área escolhida para aplicação e teste da metodologia proposta, pertence à bacia do rio Maranhão, na região noroeste do Distrito Federal (Figura 2) sendo limitada pelas coordenadas UTM 8.282.800 N, 8.272.300 S, 821.000 L e $810.750 \mathrm{~W}$, abrangendo, aproximadamente, uma área de $69,2 \mathrm{Km}^{2}$. Os principais 
afluentes do rio da Palma são os córregos Roncador e Poço Azul à leste da área e os córregos Monjolinho e Taquari à oeste.

O rio da Palma está localizado a cerca de $80 \mathrm{~km}$ de Brasília no seu ponto mais distante e a cerca de $50 \mathrm{~km}$ nos pontos mais próximos da cidade. A principal via de acesso ao local é a rodovia BR 070, em direção a Brazilândia, rumo ao município de Águas Lindas.

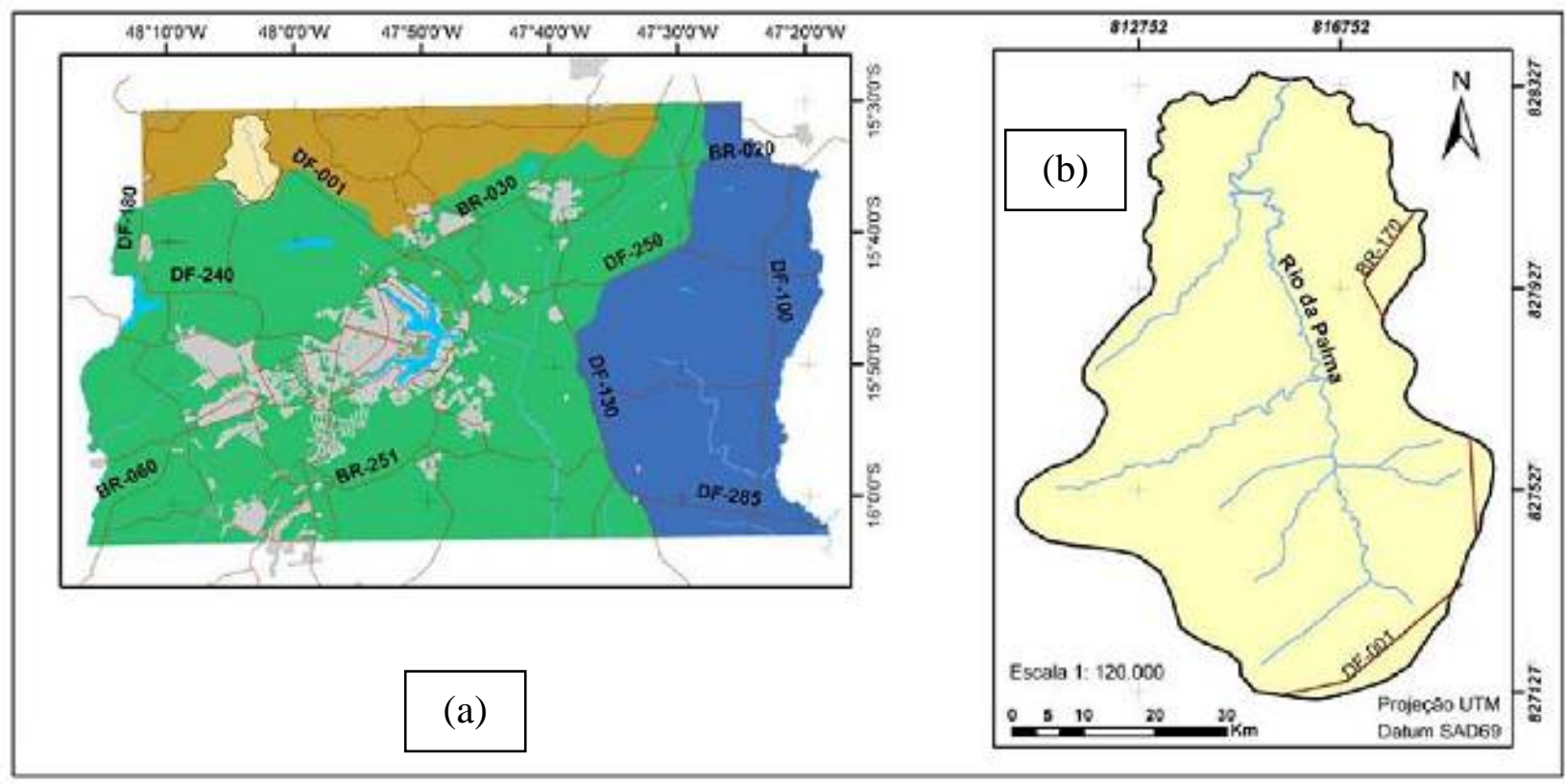

Figura 2. Localização da área de estudo (a) no contexto do Distrito Federal; (b) Bacia do Rio da Palma.

\subsubsection{Integração}

Todos os dados espaciais representados em mapas temáticos gerados ou modificados neste trabalho foram referenciados no sistema de coordenadas UTM e no Datum Planimétrico SAD-69, utilizando o software ArcView 9.0. A base de dados utilizada, em formato digital, foi integrada em um SIG para atender às propostas deste trabalho. Inicialmente, para espacializar a ocorrência dos aqüíferos da região, os sistemas fraturados e porosos foram sobrepostos de maneira a estabelecer as áreas de cada domínio. Integraram-se a este mapa base, os mapas de declividade e de uso e cobertura vegetal, com o objetivo de estabelecer as condições de infiltração e recarga na bacia estudada.

\subsection{Geologia e Solos}

O mapa geológico do Distrito Federal, confeccionado pelo Departamento Nacional de Produção Mineral (DNPM) em 1988 e modificado por Campos e Silva (1998) , na escala de 1:100.000, foi usado para delimitar os aqüíferos do domínio fraturado em função do comportamento hidrodinâmico das unidades geológicas (Figura 3).

Os estudos realizados por Campos e Silva (1998) integraram dados preexistentes e redefiniram os principais domínios aqüíferos fraturados do Distrito Federal de acordo com os novos dados geológicos. Fatores como a alta ruptibilidade das rochas, a abertura das fissuras e a interconectividade foram levados em consideração para classificar os aqüíferos fraturados com boa potencialidade hídrica, ao passo que, condições de silicificação dos espaços planares e a plasticidade das rochas, com diminuição dos espaços vazios, foram adotadas como critérios de classificação para os aqüíferos menos produtivos.

Campos e Silva (1998) classificaram o domínio fraturado nos seguintes sistemas: Paranoá, Canastra, Araxá e Bambuí. Na área em estudo, observa-se apenas a ocorrência do 
Sistema Aqüífero Paranoá, que é subdividido em cinco subsistemas (S/A, A, $\mathbf{R}_{\mathbf{3}} / \mathbf{Q}_{\mathbf{3}}, \mathbf{R}_{\mathbf{4}}$ e PPC), dos quais três encontram-se na bacia estudada: os subsistemas $\mathbf{R}_{\mathbf{3}} / \mathbf{Q}_{\mathbf{3}}$ (que incluem as unidade $\mathbf{R}_{\mathbf{3}^{-}}$Metarritmito Arenoso e $\mathbf{Q}_{\mathbf{3}}$ Quartzito Médio), $\mathbf{R}_{\mathbf{4}}$ (Unidade Metarritmito Argiloso) e PPC (Unidade Psamo-Pelito-Carbonatada).

O Subsistema $\mathbf{R}_{\mathbf{3}} / \mathbf{Q}_{\mathbf{3}}$ caracteriza-se por aqüíferos descontínuos, livres ou confinados, com extensão lateral variável, condutividade hidráulica média de $1,6 \times 10^{-6} \mathrm{~m} / \mathrm{s}$, e vazões médias de $12.000 \mathrm{~L} / \mathrm{h}$. Tais aqüíferos também são importantes por possuírem água de boa qualidade e por terem capacidade de armazenamento e vazão específica altas.

O Subsistema $\mathbf{R}_{\mathbf{4}}$ apresenta várias características desfavoráveis sob o ponto de vista hidrogeológico. A média de vazão é moderada, em torno de $6.000 \mathrm{~L} / \mathrm{h}$. São aqüíferos restritos lateralmente, livres, descontínuos, com baixa condutividade hidráulica e com alta incidência de poços secos ou de baixa produtividade.

O Subsistema PPC, com vazão média em torno de 9.000L/h, é aqüífero do tipo cárstico, descontínuo, anisotrópico e limitado por lentes carbonáticas. Esse sistema produz águas bicarbonatadas de cálcio e magnésio.

Com base nos parâmetros hidrogeológicos dos subsistemas anteriormente descritos, foram definidos os aqüíferos fraturados da bacia em estudo. A representação gráfica no mapa hidrogeológico da região do rio da Palma seguiu a proposta previamente descrita, diferenciando os respectivos sistemas por cores (Figura 4).

O mapa de solos utilizado para classificar os aqüíferos do domínio poroso da região foi modificado a partir do Mapa de Reconhecimento de Solos de EMBRAPA (1978), em escala 1:100.000 (Figura 5), para o Distrito Federal e a denominação dos tipos de solo foi adequada às especificações recomendadas pelo Sistema Brasileiro de Classificação de Solos - SBCS da EMBRAPA (1999).

Os aqüíferos do domínio poroso estão associados ao manto de intemperismo, no qual a água está armazenada nos espaços intergranulares dos materiais constituintes (solo e saprolito).

Esses sistemas funcionam como armazenadores de água, regulando as vazões dos canais superficiais durante o período de estiagem e desempenhando importante papel nos processos de recarga. Com base na espessura e condutividade hidráulica dos solos, Campos e Silva (1998) propõem quatro sistemas em ordem decrescente de importância hidrogeológica, a saber: sistemas: $\mathrm{P}_{1}, \mathrm{P}_{2}, \mathrm{P}_{3}$ e $\mathrm{P}_{4}$.

Os sistemas $\mathrm{P}_{1}, \mathrm{P}_{2}$ e $\mathrm{P}_{3}$ são compostos por solos profundos, variando de 10 a 15 metros, e condutividades hidráulicas distintas, alta (de $1,2 \times 10_{-5}^{-4}$ a $9,9 \times 10^{-5} \mathrm{~m} / \mathrm{s}$ ), média (de $6,0 \times 10^{-5}$ a $4,0 \times 10^{-5} \mathrm{~m} / \mathrm{s}$ ) e baixa (de $3,1 \times 10^{-5}$ a $6,5 \times 10^{-6} \mathrm{~m} / \mathrm{s}$ ). O sistema $\mathrm{P}_{4}$ é constituído por solos com pequenas espessuras, variando entre $2,5 \mathrm{~m}$ e $1,0 \mathrm{~m}$, e baixa condutividade hidráulica, em torno de 1,2 a $6,1 \times 10^{-7} \mathrm{~m} / \mathrm{s}$. 
Gonçalves, T. D.; Campos, J. E. G.; Batista, G. T.; Diniz, H. N.; Targa, M. S. Metodologia para elaboração de mapas hidrogeológicos: estudo de caso da bacia hidrográfica do rio da Palma, DF, Brasil. Ambi-Agua, Taubaté, v. 2, n. 2, p. 47-68, 2007. (doi:10.4136/ambi-agua.26)

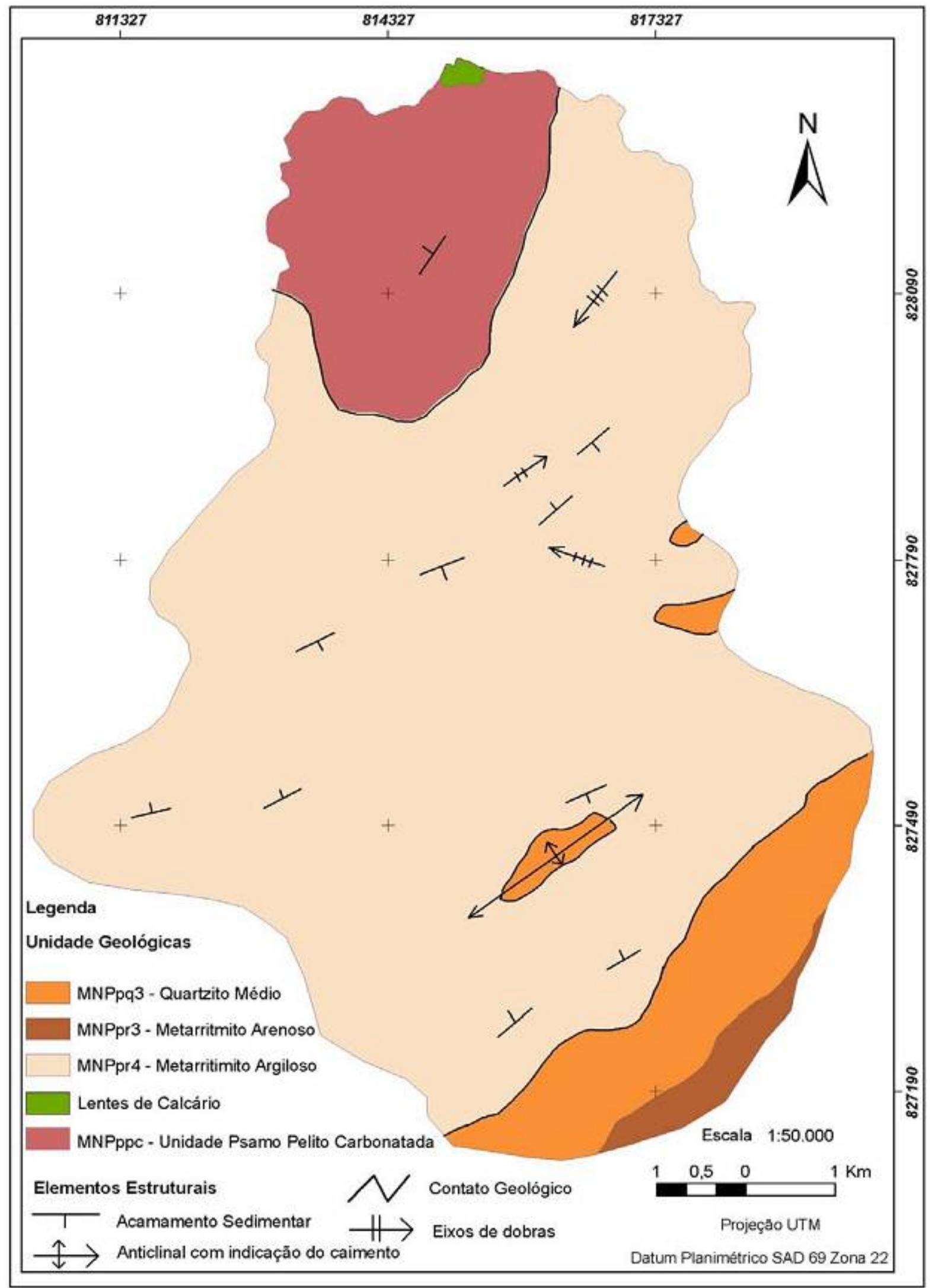

Figura 3. Mapa das Unidades Geológicas da Bacia do Rio da Palma (modificado de Campos; Silva, 1998). 
Os solos da região do rio da Palma que apresentaram características similares em termos de meio físico foram agrupados de forma a compor áreas homogêneas sob o ponto de vista do comportamento hídrico. Para agrupar as classes de solo, foram considerados os parâmetros hidrodinâmicos conforme descritos por Campos e Silva (1998), o que resultou nos seguintes domínios porosos: $\mathrm{P}_{1}, \mathrm{P}_{2}$ e $\mathrm{P}_{4}$ (Tabela 2).

A representação desses sistemas no mapa hidrogeológico da região em estudo se dá por hachuras em diferentes direções conforme mostrado na Figura 6.

Tabela 2. Caracterização simplificada dos sistemas porosos da área em estudo.

\begin{tabular}{|c|l|}
\hline Sistema & Agrupamento / Solos Predominantes \\
\hline $\mathrm{P}_{1}$ & Latossolo Vermelho-Amarelo (LVA) de textura arenosa. Neossolos flúvicos. \\
\hline $\mathrm{P}_{2}$ & Latossolo Vermelho (LV) arenoso a argiloso. Nitossolo \\
\hline $\mathrm{P}_{4}$ & Cambissolo e Plintossolo Pétrico. \\
\hline
\end{tabular}

\subsection{Declividade e Cobertura Vegetal}

Com o objetivo de se determinar as condições de infiltração e recarga da região em estudo, fez-se necessário integrar aos sistemas aqüíferos, os mapas de declividade e de uso e cobertura vegetal.

Para a criação do mapa de declividade foram executados, no programa ArcView, usando a extensão $3 D$ Analyst. A partir de mapas vetoriais plani-altimétricos da Companhia de Desenvolvimento do Planalto - CODEPLAN (1992) foram editados 570 pontos cotados e curvas de nível com eqüidistância de $5 \mathrm{~m}$. A edição dos dados foi necessária para correção de erros, tais como: curvas de nível - eliminação de isolinhas sobrepostas e junção de isolinhas descontínuas - e pontos cotados - edição dos pontos e alimentação da tabela com o atributo "cota”.

Com os pontos cotados, as curvas de nível, a drenagem e o limite da área, procedeu-se a criação do TIN (Triangular Regular Network) - tipo de MDE que representa a superfície por meio de um conjunto de faces triangulares interligadas - possibilitando a representação mais fiel das variações de altura do terreno. Gerou-se, então, o mapa de declividade a partir do TIN com 5 classes.

Para a confecção do mapa de uso e cobertura vegetal da bacia do rio da Palma, foi utilizada uma imagem do sensor de alta resolução HRV (High Resolution Visible), a bordo do satélite SPOT (Systeme Probatoire d' Odservation de la Terre), datada de 29/04/2003, bandas XS1, XS2 e XS3.

Utilizou-se composição colorida RGB-321 e procedeu-se, então, a aplicação de realce por ampliação linear de contraste em cada banda da imagem, visando à melhoria das características visuais. Em seguida, procedeu-se a correção geométrica por georreferenciamento, segundo a técnica de transformação geométrica polinomial, baseada em pontos de controle (GCP - ground control points). Essa técnica consiste em estabelecer relações matemáticas entre as posições dos pixels na imagem e suas coordenadas no terreno com o objetivo de reorganizar os pixels das imagens, de forma a permitir o registro (sobreposição) dos diversos mapas utilizados.

Utilizando-se o software ENVI, foi realizado o registro da imagem SPOT, tendo como base a carta plano-altimétrica do Rio da Palma (MI-2214-2-NE) do IBGE. 

mapas hidrogeológicos: estudo de caso da bacia hidrográfica do rio da Palma, DF, Brasil. Ambi-Agua, Taubaté, v. 2, n. 2, p. 47-68, 2007. (doi:10.4136/ambi-agua.26)

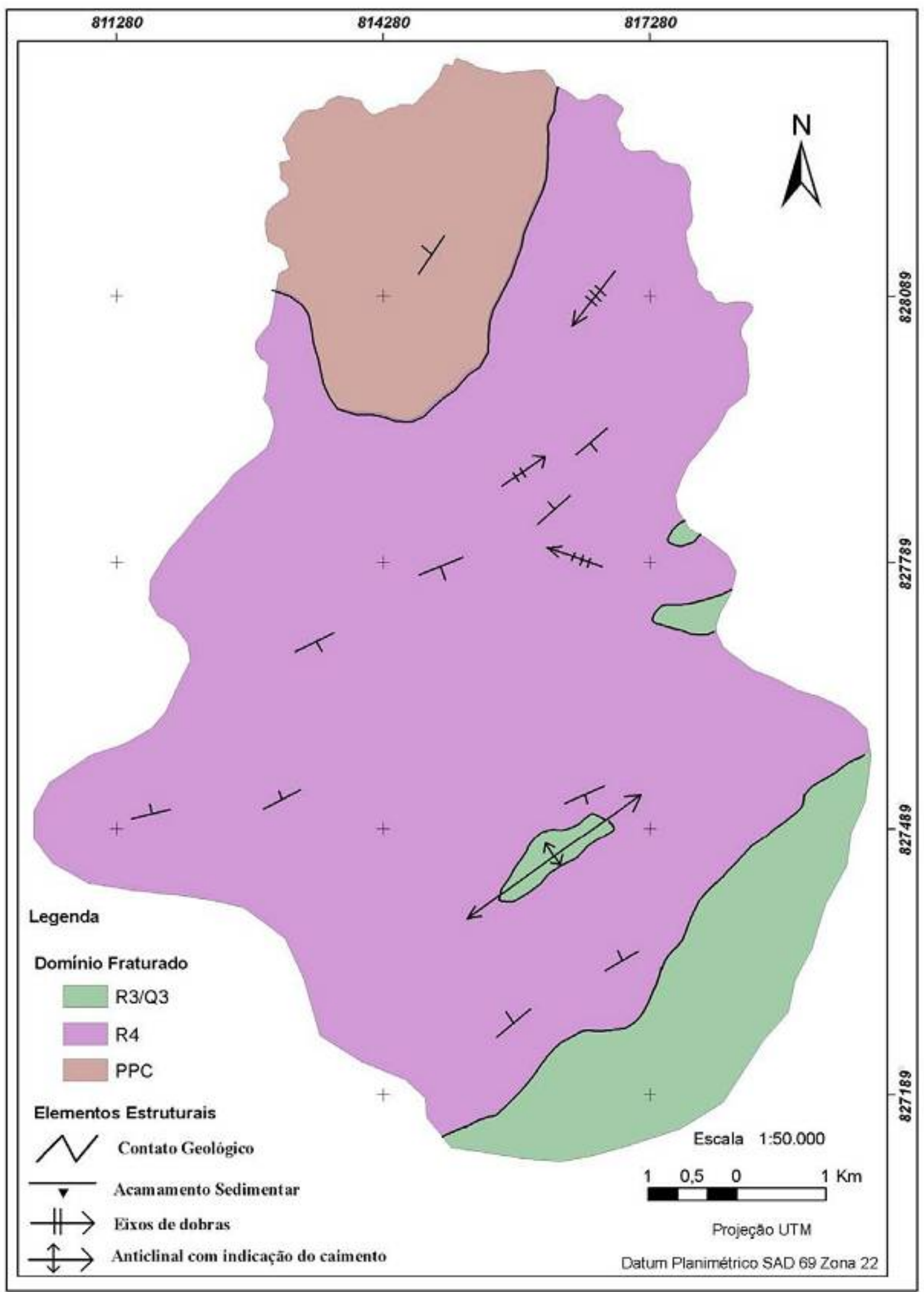

Figura 4. Sistemas Aqüíferos do Domínio Fraturado da Bacia do Rio da Palma. $\mathbf{R}_{\mathbf{3}}$ - Metarritmito Arenoso; $\mathbf{Q}_{\mathbf{3}^{-}}$Quartzito Médio); $\mathbf{R}_{\mathbf{4}}$ - Unidade Metarritmito Argiloso; e PPC - Unidade PsamoPelito-Carbonatada). 
Gonçalves, T. D.; Campos, J. E. G.; Batista, G. T.; Diniz, H. N.; Targa, M. S. Metodologia para elaboração de mapas hidrogeológicos: estudo de caso da bacia hidrográfica do rio da Palma, DF, Brasil. Ambi-Agua, Taubaté, v. 2, n. 2, p. 47-68, 2007. (doi:10.4136/ambi-agua.26)

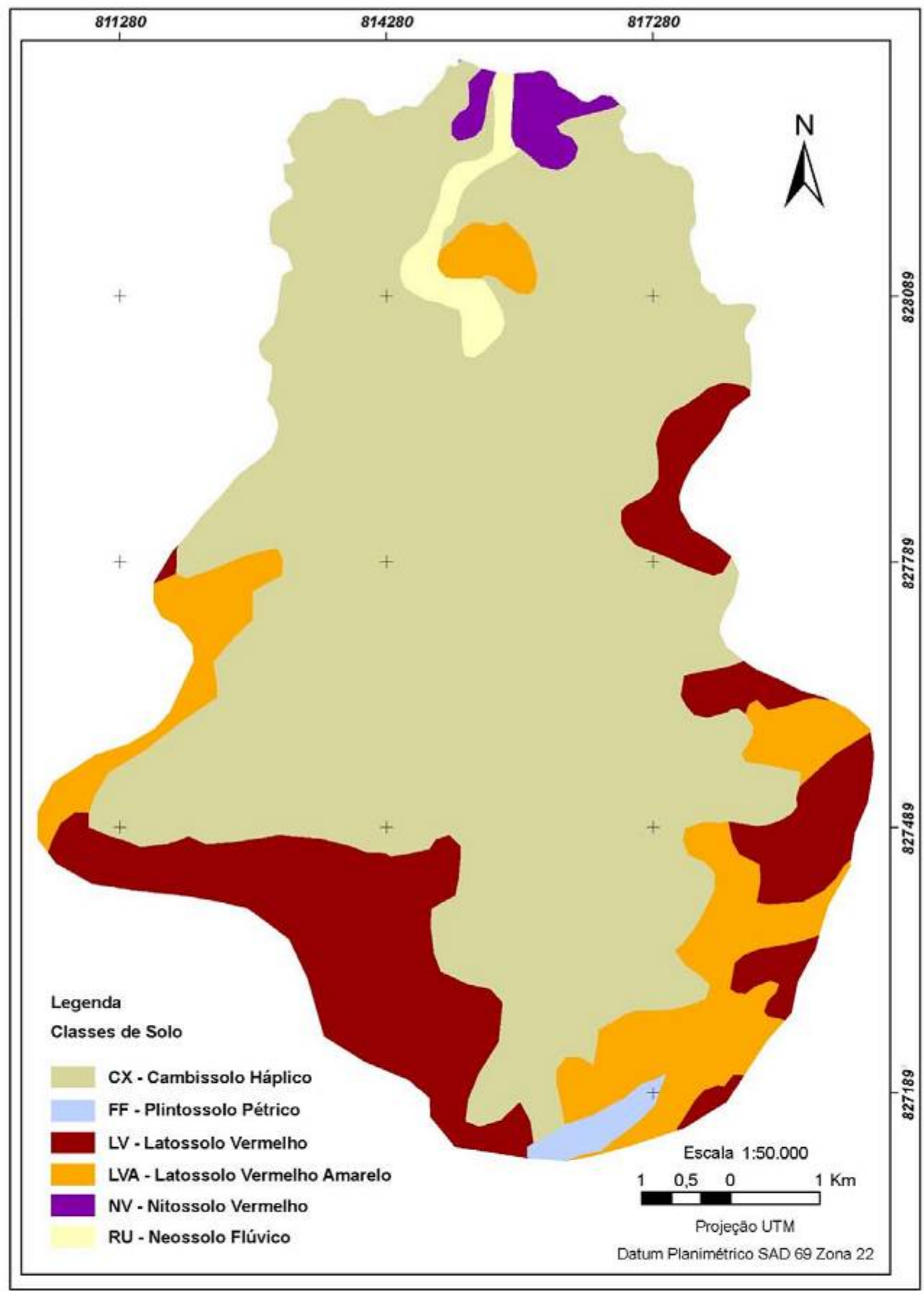

Figura 5. Mapa de Solos da Bacia do Rio da Palma (modificado de EMBRAPA, 1978). 
Gonçalves, T. D.; Campos, J. E. G.; Batista, G. T.; Diniz, H. N.; Targa, M. S. Metodologia para elaboração de mapas hidrogeológicos: estudo de caso da bacia hidrográfica do rio da Palma, DF, Brasil. Ambi-Agua, Taubaté, v. 2, n. 2, p. 47-68, 2007. (doi:10.4136/ambi-agua.26)

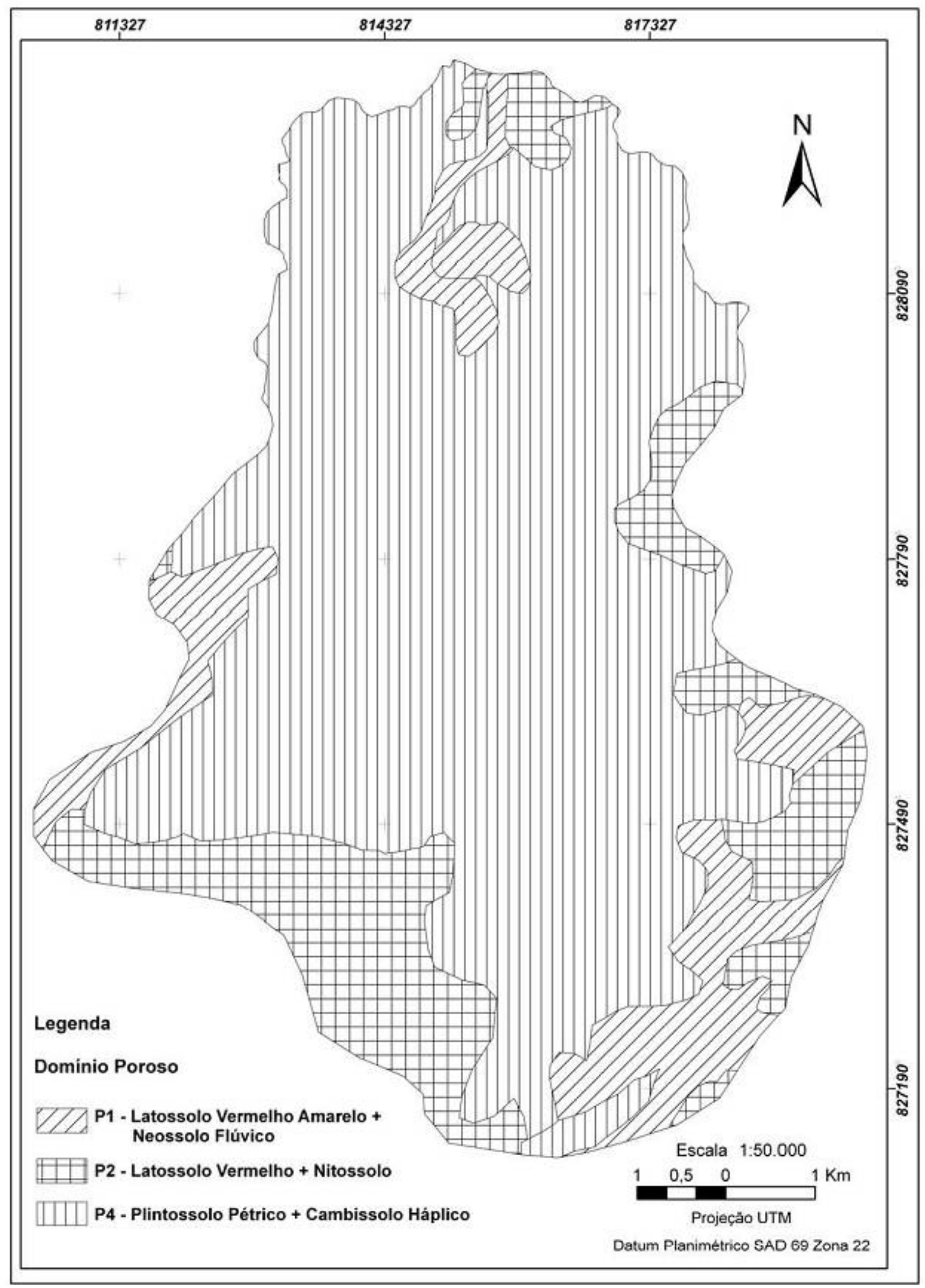

Figura 6. Sistemas Aqüíferos do Domínio Poroso da Bacia do Rio da Palma. 
Foram utilizados cinqüenta (50) pontos de controle para a realização desse registro. Utilizou-se um polinômio de grau 1 para relacionar as linhas e colunas da imagem com as coordenadas do mapa, e para a definição dos novos valores de brilho da imagem, a técnica do "vizinho mais próximo", resultando em uma boa qualidade do registro, ou seja em um RMS de 0,37 pixels, ou seja, um erro de 7,4m, menor que a resolução espacial da imagem (20m). Coordenadas retransformadas dentro da mencionada margem de erro são consideradas corretas, segundo Meneses e Madeira (2001).

A interpretação da imagem SPOT consistiu em extrair informações de alvos da superfície da área de interesse com base em suas respostas espectrais. A classificação de imagens multiespectrais é o processo de associação dos pixels de um conjunto de bandas de uma imagem a um número limitado de classes individuais que representem os objetos do mundo real, com base nos seus valores digitais. A imagem classificada é, assim, uma forma de mapa temático digital.

O fator que pode determinar a utilização de uma classificação supervisionada ou não supervisionada é o conhecimento do analista sobre a região. Para a classificação supervisionada, os dados de treinamento são utilizados para "treinar" os algoritmos de classificação para que esse possa classificar o restante da imagem, com base no cálculo da probabilidade de cada classe no espaço de amostras. Uma vez definidas as probabilidades das classes e, conseqüentemente, suas assinaturas espectrais, os algoritmos de classificação devem ser capazes de gerar relatórios tabulares e mapas temáticos representando o resultado da classificação. Assim, o mapa de uso e cobertura vegetal da bacia do rio da Palma foi produzido a partir da classificação e vetorização da imagem SPOT no software ENVI. Uma vez analisados os resultados da classificação, ela foi refinada usando um algoritmo de pósclassificação (classification to vector), para a edição do mapa temático utilizando o software ArcView GIS. As classes foram, assim, reclassificadas, em parte, "manualmente”, a critério do analista, tendo resultado no Mapa de Uso e Cobertura Vegetal da Bacia do Rio da Palma (Figura 7).

Este mapa teve suas classes ponderadas de acordo com o potencial de infiltração em função do uso da terra e da cobertura vegetal.

\subsection{Mapa Hidrogeológico}

Os planos de informação utilizados para a confecção do mapa hidrogeológico foram sobrepostos de maneira a integrar os sistemas aqüíferos do domínio poroso com os do domínio fraturado. Os dois principais parâmetros integrados para determinar espacialmente ambos os domínios foram as médias de vazões de cada sistema/subsistema aqüífero fraturado e o tipo de sistema poroso que os recobrem. Esses parâmetros foram compilados da proposta de Campos e Silva (1998) para aqüíferos do Distrito Federal.

A representação gráfica dos respectivos domínios seguiu a proposta já apresentada para aqüíferos sobrepostos. O domínio fraturado foi representado por cores e o domínio poroso por hachuras em diferentes padrões. Na Figura 8, é apresentado o Mapa Hidrogeológico do Alto Curso da Bacia do Rio da Palma na escala 1:50.000.

\subsection{Condições de Infiltração e Recarga}

A capacidade de infiltração e armazenamento de água dos sistemas aqüíferos de uma bacia está relacionada, basicamente, aos fatores: geologia, solos, declividade e uso e cobertura vegetal. Assim, para que as condições de infiltração e recarga da área em estudo pudessem ser estabelecidas, fez-se necessária a integração dos seguintes planos de informação: sistemas aqüíferos poroso e fraturado; declividade e uso e ocupação vegetal. 
Gonçalves, T. D.; Campos, J. E. G.; Batista, G. T.; Diniz, H. N.; Targa, M. S. Metodologia para elaboração de mapas hidrogeológicos: estudo de caso da bacia hidrográfica do rio da Palma, DF, Brasil. Ambi-Agua, Taubaté, v. 2, n. 2, p. 47-68, 2007. (doi:10.4136/ambi-agua.26)

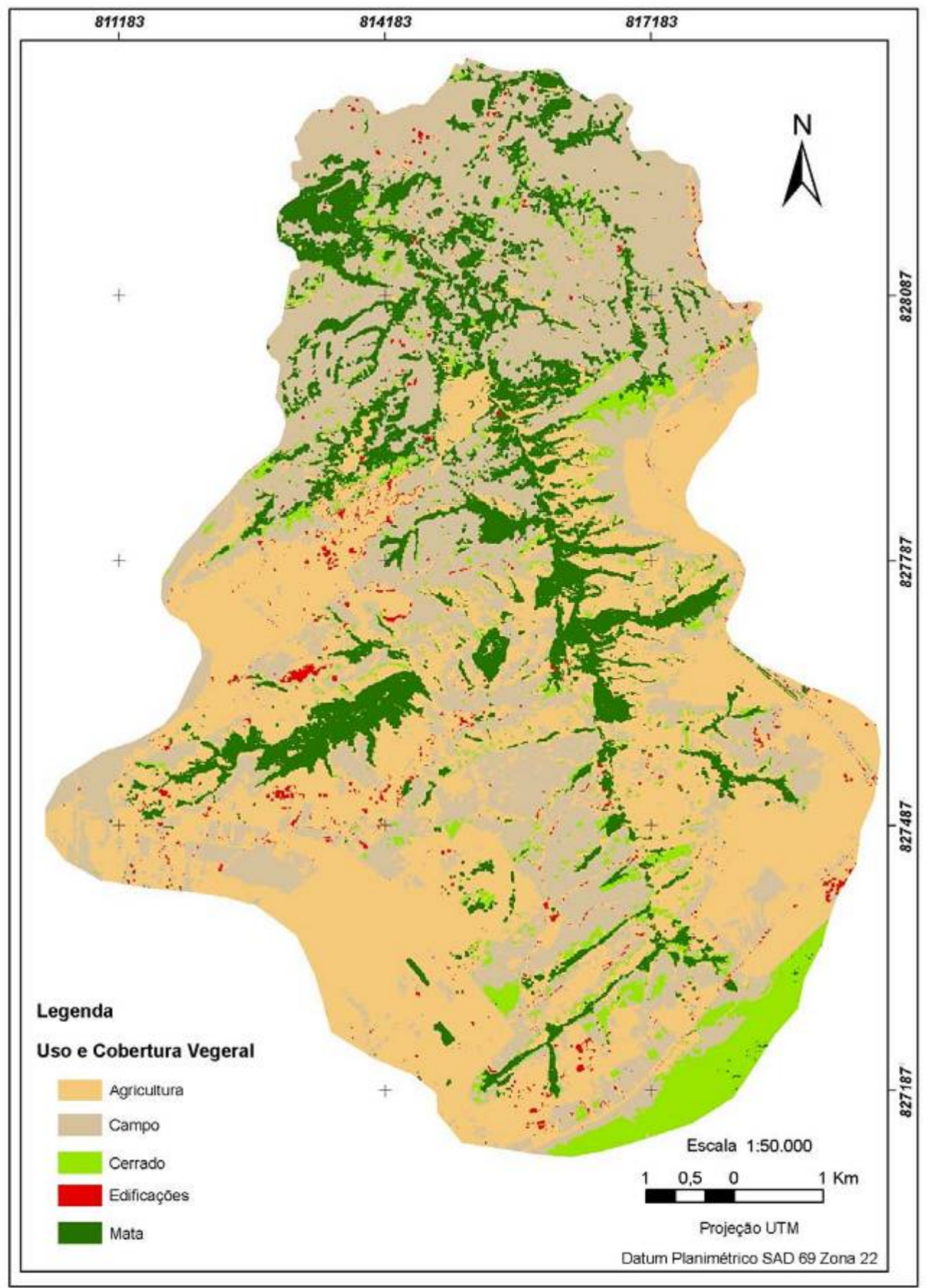

Figura 7. Mapa de Uso e Cobertura Vegetal da Bacia do Rio da Palma. 
Gonçalves, T. D.; Campos, J. E. G.; Batista, G. T.; Diniz, H. N.; Targa, M. S. Metodologia para elaboração de mapas hidrogeológicos: estudo de caso da bacia hidrográfica do rio da Palma, DF, Brasil. Ambi-Agua, Taubaté, v. 2, n. 2, p. 47-68, 2007. (doi:10.4136/ambi-agua.26)

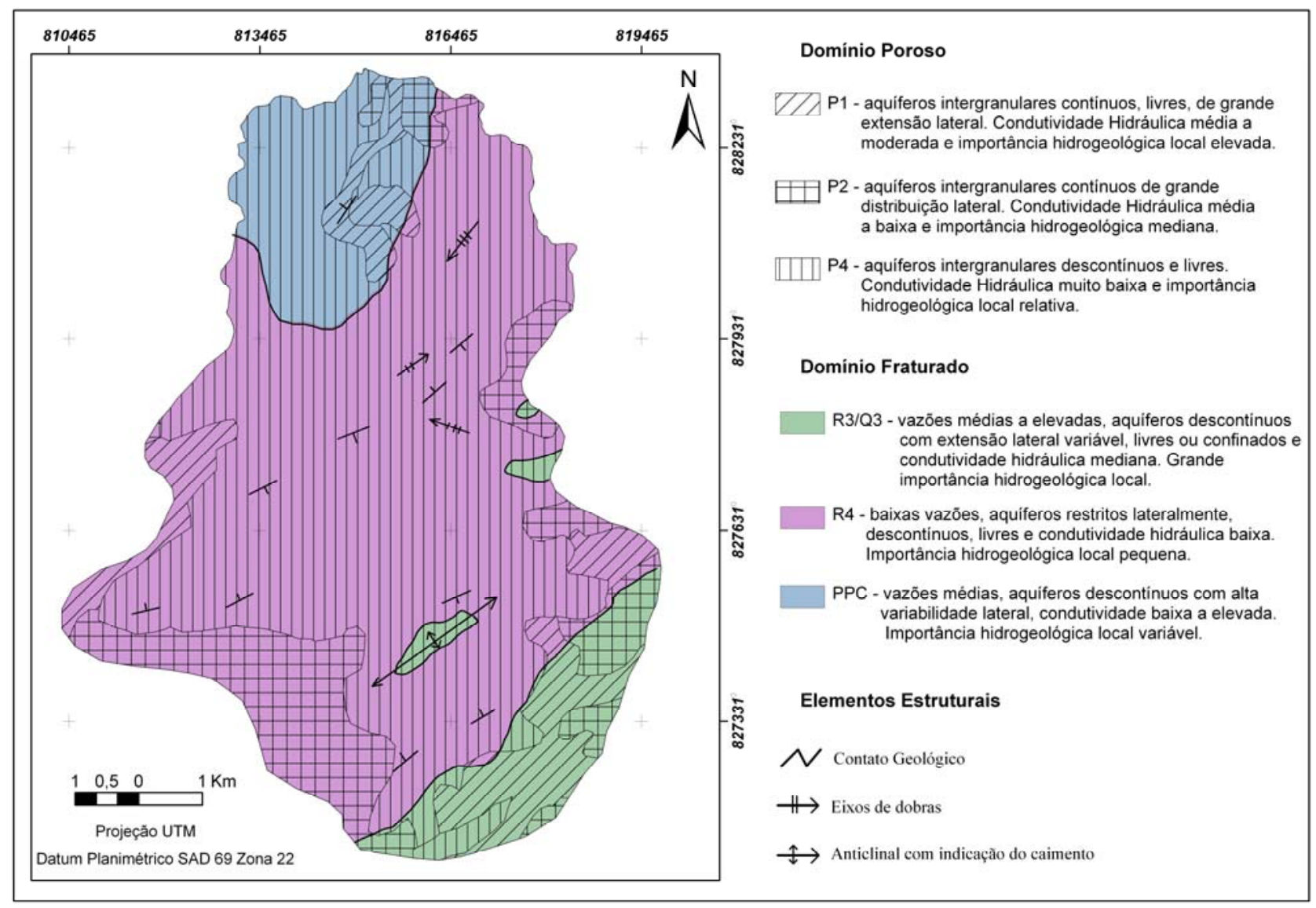

Figura 8. Mapa Hidrogeológico do Alto Curso da Bacia do Rio da Palma.

A integração dos dados se deu por meio de um SIG, em que cada plano de informação, ponderado de acordo com a capacidade de infiltração dos seus respectivos parâmetros, foi sobreposto de forma que as intersecções resultantes pudessem ser representativas das diferentes condições de infiltração e recarga da bacia em estudo.

O método escolhido para interpretação dos resultados foi a análise combinatória da soma dos pesos das classes, diferenciadas por fatores numéricos decimais. Cada parâmetro foi analisado e interpretado de acordo com as condições de infiltração e recarga representadas por suas faixas de pesos, conforme mostram as Tabelas 3, 4 e 5.

O mapa resultante da sobreposição e integração das bases de dados foi interpretado e reagrupado, gerando um mapa final com cinco classes que designam de forma qualitativa o potencial de infiltração e recarga da região estudada (Figura 9), a saber: Potencial Muito Alto, Potencial Alto, Potencial Moderado, Potencial Baixo e Potencial Muito Baixo. 
Gonçalves, T. D.; Campos, J. E. G.; Batista, G. T.; Diniz, H. N.; Targa, M. S. Metodologia para elaboração de mapas hidrogeológicos: estudo de caso da bacia hidrográfica do rio da Palma, DF, Brasil. Ambi-Agua, Taubaté, v. 2, n. 2, p. 47-68, 2007. (doi:10.4136/ambi-agua.26)

Tabela 3. Ponderação das classes dos sistemas poroso e fraturado do alto curso do rio da Palma.

\begin{tabular}{|c|c|c|c|}
\hline $\begin{array}{c}\text { Plano de } \\
\text { Informação }\end{array}$ & Classe & Peso & Justificativa \\
\hline \multirow{3}{*}{ Sistema Poroso } & $\mathbf{P}_{2}$ & 5000 & $\begin{array}{c}\text { Condição ótima. Muito espesso e elevada } \\
\text { condutividade hidráulica. }\end{array}$ \\
\hline & $P_{1}$ & 4000 & $\begin{array}{l}\text { Condição boa. Condutividade hidráulica e espessura } \\
\text { média. }\end{array}$ \\
\hline & $\mathbf{P}_{4}$ & 2000 & $\begin{array}{l}\text { Condição ruim. Espessura e condutividade hidráulica } \\
\text { baixa. }\end{array}$ \\
\hline \multirow{3}{*}{ Sistema Fraturado } & $\mathbf{R}_{3} / \mathbf{Q}_{3}$ & 500 & Condição ótima. Vazões médias a elevadas. \\
\hline & PPC & 300 & $\begin{array}{l}\text { Condição média. Vazões e interconectividade de } \\
\text { fraturas medianas. }\end{array}$ \\
\hline & $\mathbf{R}_{4}$ & 200 & Condição ruim. Litologias desfavoráveis. \\
\hline
\end{tabular}

Tabela 4. Ponderação das classes de declividade do alto curso do rio da Palma.

\begin{tabular}{|c|c|c|c|}
\hline $\begin{array}{l}\text { Plano de } \\
\text { Informação }\end{array}$ & Classe & Peso & Justificativa \\
\hline \multirow{5}{*}{ Declividade } & $0 \%-8 \%$ & 50 & $\begin{array}{c}\text { Até 8\% escoamento superficial é mínimo. Ótimo } \\
\text { para infiltração e recarga, tendência de } \\
\text { desenvolvimento de fluxo difuso. }\end{array}$ \\
\hline & $8 \%-25 \%$ & 40 & $\begin{array}{c}\text { De } 8 \text { a 15\% o escoamento é brando com até 20\% } \\
\text { de infiltração (com relação à precipitação total). } \\
\text { Bom pra infiltração e recarga. }\end{array}$ \\
\hline & $25 \%-50 \%$ & 30 & $\begin{array}{l}\text { Infiltração reduzida. Regular para infiltração e } \\
\text { recarga. }\end{array}$ \\
\hline & $50 \%-75 \%$ & 20 & $\begin{array}{l}\text { Infiltração muito restrita. Ruim para infiltração e } \\
\text { recarga }\end{array}$ \\
\hline & $>75 \%$ & 10 & $\begin{array}{c}\text { Péssimo para infiltração e recarga. Ampla } \\
\text { tendência de desenvolvimento de fluxo linear } \\
\text { concentrado. }\end{array}$ \\
\hline
\end{tabular}

Tabela 5. Ponderação das classes do uso e cobertura vegetal do alto curso do rio da Palma.

\begin{tabular}{c|ccc}
\hline $\begin{array}{c}\text { Plano de } \\
\text { Informação }\end{array}$ & Classe & Peso & Justificativa \\
\hline $\begin{array}{c}\text { Uso da terra e } \\
\text { cobertura } \\
\text { vegetal }\end{array}$ & $\begin{array}{c}\text { Cerrado } \\
\text { Agricultura e Solo } \\
\text { exposto } \\
\text { Áreas Urbanas }\end{array}$ & 5 & $\begin{array}{c}\text { Grande densidade arbórea. Ótimo } \\
\text { para infiltração e recarga. } \\
\text { Boa densidade arbórea e Boa para } \\
\text { infiltração e recarga. }\end{array}$ \\
\hline
\end{tabular}


Gonçalves, T. D.; Campos, J. E. G.; Batista, G. T.; Diniz, H. N.; Targa, M. S. Metodologia para elaboração de mapas hidrogeológicos: estudo de caso da bacia hidrográfica do rio da Palma, DF, Brasil. Ambi-Agua, Taubaté, v. 2, n. 2, p. 47-68, 2007. (doi:10.4136/ambi-agua.26)

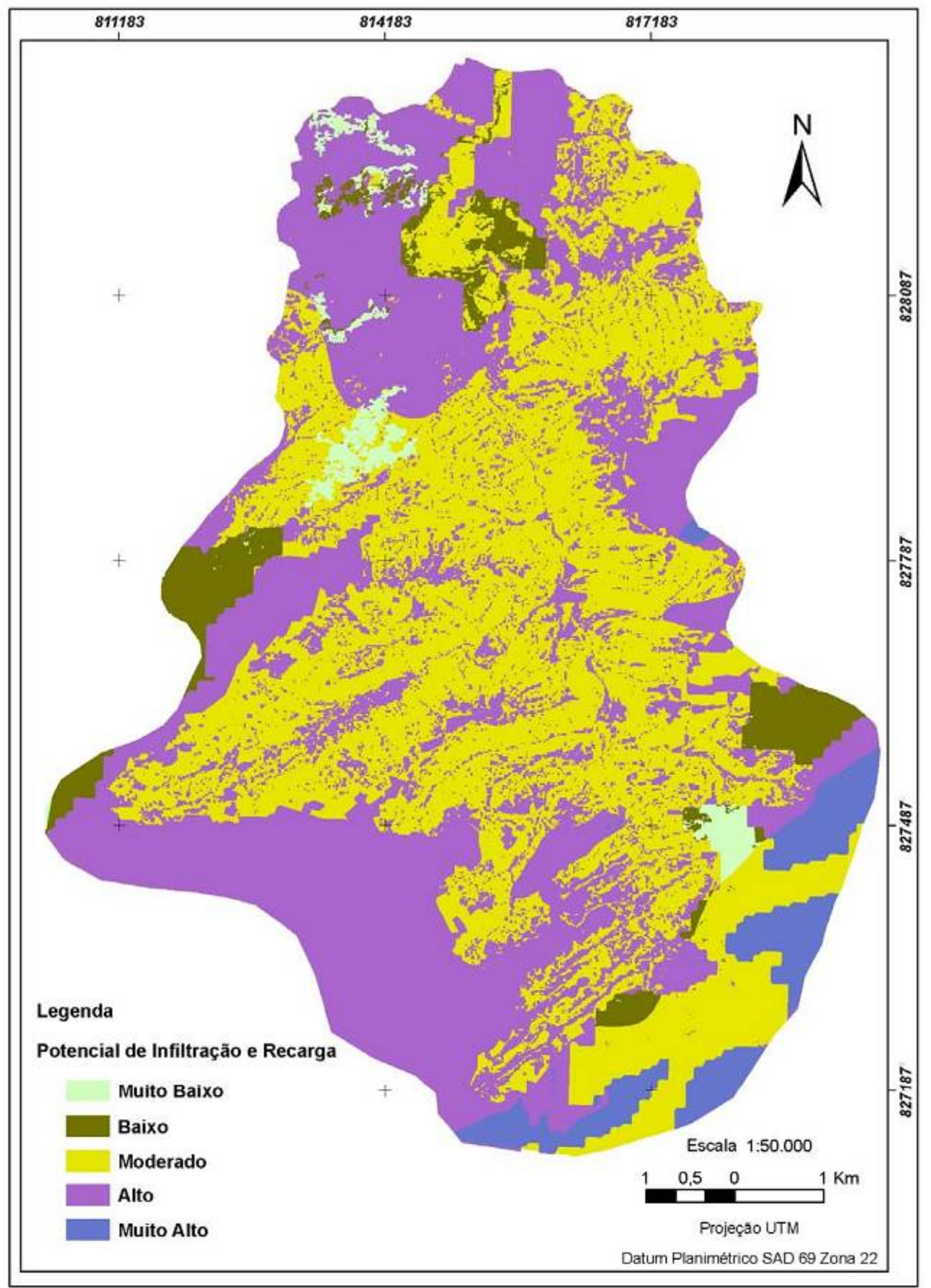

Figura 9. Mapa de Potencial de Recarga da bacia do Rio da Palma, DF. 
As áreas com potencial muito alto correspondem aos sistemas aqüíferos porosos $\mathrm{P}_{2} \mathrm{e}$ fraturado $\mathbf{R}_{3} / \mathbf{Q}_{3}$, com ocorrência em declividades menores que 8\% e vegetação preservada de mata ou cerrado. De forma geral, na área estudada, predominaram as regiões com potencial de infiltração alto e moderado, em que a interferência humana ainda é incipiente embora prevaleçam cambissolos em áreas com declividades altas. Grande parte das regiões de potencial baixo está relacionada às altas declividades ou a presença de edificações urbanas.

\section{CONSIDERAÇÕES FINAIS}

O SIG torna possível a automatização da produção de documentos cartográficos, na medida em que todas as informações disponíveis estão inter-relacionadas com base na sua localização geográfica. Os “mapas base” representam fontes de informações que passam por diferentes operações de análise espacial, lógicas e algébricas para produção de novas informações, por meio de diferentes possibilidades de integração de dados.

Os planos de informação integrados no SIG permitiram realizar as análises almejadas e estabelecer a ligação da base de dados espacial e alfanumérica. Com a integração foi possível destacar a distribuição espacial das unidades hidrogeológicas e estabelecer as condições de infiltração e recarga da porção distrital da bacia do rio da Palma.

O uso de diferentes formas de representação cartográfica permite que sejam lançadas em um único mapa, informações de naturezas diferentes como é o caso dos domínios aqüíferos rasos (intergranulares) e profundos (fraturados) da bacia do rio da Palma. O uso de hachuras e cores permitiu o mapeamento e a sobreposição de grande número de informações sobre a água subterrânea da referida bacia.

A sobreposição de diferentes planos de informação é efetiva para a construção de mapas de potencial de recarga de aqüíferos e como esse produto cartográfico é dependente das intervenções humanas na bacia, sua atualização pode ser facilitada com a produção de novos mapas de uso e cobertura vegetal.

A qualidade do mapa hidrogeológico é diretamente vinculada à qualidade das bases cartográficas utilizadas para sua confecção, principalmente, dos mapas de geologia e de solos.

A proposta para mapeamento de aqüíferos sobrepostos, utilizada no presente trabalho, considera a existência de informações essenciais e acessórias. Dentro do conjunto de informações essenciais, destacam-se: geologia, solos, cadastro de pontos d'água, geomorfologia, dados hidrodinâmicos e lineamentos. Dentre as informações acessórias, clima, relevo, dados de hidroquímica e risco de contaminação merecem destaque.

No que diz respeito à gestão dos recursos hídricos, o conhecimento da disponibilidade dos sistemas aqüíferos e da qualidade de suas águas é primordial para estabelecer políticas integradas de gerenciamento das águas. Iniciativas que visem fornecer documentação técnica como o Mapa Hidrogeológico e de Potencial de Infiltração e Recarga do Alto Curso da Bacia do Rio da Palma constituem importantes fontes de informações para o planejamento e execução de políticas públicas. Entretanto, a despeito do crescimento populacional e da crescente exploração de água subterrânea, uma adequada gestão das águas requer investimentos na área técnica capazes de garantir a constante atualização da base de dados, a fim de que seja assegurada a utilização sustentável dos recursos hídricos. 


\section{REFERÊNCIAS}

AMORE, L. Fundamentos para uso e proteção das águas subterrâneas do Distrito Federal. 1994. 142f. Dissertação (Mestrado em Engenharia) - Escola de Engenharia de São Carlos, Universidade de São Paulo, São Carlos, 1994.

BARBOSA, R. P. O sistema de atlas complexo de planejamento do Brasil. Revista Brasileira de Geografia, Rio de Janeiro, v. 39, n. 3, p. 144-150, 1977.

BARROS, J. C. B. Geologia e hidrogeologia do Distrito Federal. In: GDF/CAESB. Inventário hidrogeológico do Distrito Federal. Brasília: SEMATEC/IEMA, 1987. p. 79-330.

BARROS, J. G. C. Características geológicas e hidrogeológicas do Distrito Federal. In: UnB/SEMATEC. Cerrado, caracterização, ocupação e perspectivas: o caso do Distrito Federal. Brasília: SEMATEC/IEMA,1994. 657p.

BOVOLATO, L. E. Caracterização Geoquímica das Águas Subterrâneas de Araguaína/TO. Caminhos de Geografia, Uberlândia, v. 2, n. 17, p. 8-19, 2006. Disponível em: $<$ http://www.ig.ufu.br/revista/caminhos.html>. Acesso em julho de 2007.

BURROUGH, P. A. Principles of geographic information systems for land resources assessment: monographs on soil and resources survey. Oxford: Clarendon Press, 1986. $194 \mathrm{p}$.

CADAMURO, A. L. M. Proposta, avaliação e aplicabilidade de técnicas de recarga artificial em aqüíferos fraturados para condomínios residenciais do Distrito Federal. 126f. 2002. Dissertação (Mestrado em Processamento de Dados em Geologia e Análise Ambiental) - Instituto de Geociências, Universidade de Brasília, Brasília, 2002.

CAMPOS, J. E. G. Hidrogeologia do Distrito Federal: bases para a gestão dos recursos hídricos subterrâneos. Revista Brasileira de Geociências, São Paulo, v. 34, n. 1, p. 4148, 2004.

CAMPOS, J. E. G.; SILVA, F. H. S. Hidrogeologia do Distrito Federal. In: Inventário hidrogeológico e dos recursos hídricos superficiais do Distrito Federal. Brasília: IEMA/SEMATEC/UnB, 1998. p. 01-85. vol. 4.

CARVALHO, J. R. P.; ASSAD, E. D. Comparação de interpoladores espaciais univariados para precipitação pluvial anual no Estado de São Paulo. Campinas: Embrapa/CNPTIA, 2002. 6p. Comunicado técnico 33.

COMPANHIA DE PLANEJAMENTO DO DISTRITO FEDERAL. Mapas topográficos plani-altimétricos digitais do Distrito Federal. Brasília: CODEPLAN, 1992. Escala $1: 10.000$.

EMPRESA BRASILEIRA DE PESQUISA AGROPECUÁRIA. Levantamento de reconhecimento dos solos do Distrito Federal. Rio de Janeiro: SNLCS/EMBRAPA, 1978. 455 p. Boletim Técnico 53.

Sistema brasileiro de classificação de solos. Brasília: SPI, 1999. 
INSTITUTO BRASILEIRO DE GEOGRAFIA E ESTATÍSTICA. Noções Básicas de Cartografia. Rio de Janeiro: IBGE/Departamento de Cartografia, 2005.

JOKO, C. T. Hidrogeologia da região de São Sebastião - DF: implicações para a gestão do sistema de abastecimento de água. 158f. 2002. Dissertação (Mestrado em Processamento de Dados em Geologia e Análise Ambiental) - Instituto de Geociências, Universidade de Brasília, Brasília, 2002.

LOUSADA, E. O.; CAMPOS, J. E. G. Proposta de modelos hidrogeológicos conceituais aplicados aos aqüíferos da região do Distrito Federal. Revista Brasileira de Geociências, São Paulo, v. 35, n. 3, p. 407-414, 2005.

MELO JÚNIOR, G.; COSTA, C. E. F. S.; CABRAL NETO, I. Avaliação hidroquímica e da qualidade das águas de um trecho do Rio Açu, Rio Grande do Norte. Revista de Geologia, Fortaleza, v. 16, n. 2, p. 27-36, 2003. Disponível em: <http://www. revistadegeologia.ufc.br/14_2003.pdf>. Acesso em julho 2007.

MENDONÇA, A. F. Caracterização da erosão subterrânea nos aqüíferos porosos do Distrito Federal. Anexo 3a: Reservas de água de superfície do Parque Nacional de Brasília. 154f. 1993. Dissertação (Mestrado em Geologia Econômica e Prospecção) Instituto de Geociências, Universidade de Brasília, Brasília, 1993.

MENESES, P. R.; MADEIRA, J. S. N. Sensoriamento remoto: reflectância dos alvos naturais. Brasília: UnB/EMBRAPA, 2001. 262p.

MENTE, A. Classificação e utilização de mapas hidrogeológicos. In: FEITOSA, E. C. (Org.) Hidrogeologia: conceitos e aplicações. 2. ed. Fortaleza: CPRM/REFO, LABHID UFPE, 2000. p.175-182.

ROMANO, O.; ROSAS, J. G. C. Água subterrânea para fins de abastecimento de água e irrigação no Distrito Federal. In: CONGRESSO BRASILEIRO DE GEOLOGIA, 24., 1970, Brasília. Anais... Brasília: SBG, 1970. p. 313-333.

SOUZA, M. T. Fundamentos para a gestão dos recursos hídricos subterrâneos no Distrito Federal. 124f. 2001. Dissertação (Mestrado em Processamento de Dados em Geologia e Análise Ambiental) - Instituto de Geociências, Universidade de Brasília, Brasília, 2001.

VIEIRA, L. S. Manual de ciência do solo: com ênfase aos solos tropicais. 2. ed. São Paulo: Agronômica Ceres, 1988. 464p.

ZOBY, J. L. G. Hidrogeologia de Brasília: bacia do Ribeirão Sobradinho. 178f. 1999. Dissertação (Mestrado em Recursos Minerais e Hidrogeologia) - Instituto de Geociências, Universidade de São Paulo, São Paulo, 1999. 